\title{
Effect of Tsunami in the Ilmenite Population: An Examination through X-Ray Diffraction, Scanning Electron Microscopy and Inductively Coupled Plasma Atomic Emission
}

\author{
Babu Nallusamy ${ }^{1}$, Sinirani Babu ${ }^{1}$, M. Sundararajan ${ }^{2}$, P. Seralathan ${ }^{1}$, R. Bhima Rao ${ }^{3}$ \& \\ P.N. Mohan Das ${ }^{2}$ \\ ${ }^{1}$ Cochin University of Science and Technology, Kerala, India. \\ ${ }^{2}$ National Institute for Interdisciplinary Science and Technology (CSIR), Trivandrum, India \\ ${ }^{3}$ Institute of Minerals and Materials Technology, Bhubaneswar, Orissa, India \\ *Corresponding Author: geobns@gmail.com
}

\begin{abstract}
Kerala state in the SW part of Indian subcontinent hosts one of the best beach placer deposits in the world. The near shore deposit is 140Mt and is very rich in heavy minerals, often up to $70 \%$, and ilmenite forms its chief constituent. The seasonal enrichment of this deposit takes place through monsoonal activity and the recent tsunami (24 December 2004) had significantly contributed its share. Mineralogical and chemical variation of the surface (pre- and posttsunamigenic) as well as subsurface ilmenites (4-5m depth) of this deposit has been investigated. SEM examination on ilmenites of pre-tsunamigenic period conveys that the micromorphology represents mostly of mechanical activities rather than chemical and solution activities. Both post-tsunamigenic and subsurface ilmenites were influenced dominantly by solution and chemical alteration. The pre-tsunamigenic (surficial) ilmenite grains consist only of rutile as an altered product with a small $\mathrm{FeO}-\mathrm{Fe}_{2} \mathrm{O}_{3}$ ratio. However, the presence of considerable altered products such as rutile and pseudorutile in the post-tsunamigenic and subsurface ilmenite indicates that the ilmenite alteration is in an advanced state. Regarding trace element composition, it was found that $\mathrm{Al}, \mathrm{Mg}, \mathrm{Na}, \mathrm{Ca}, \mathrm{Cd}, \mathrm{Co}, \mathrm{K}, \mathrm{Sr}$ and $\mathrm{Pb}$ have higher contents in both core and post-tsunamigenic ilmenite than the pre-tsunamigenic ilmenite. These elements play an important role in understanding the behavior of the minerals during beneficiation and further processing. The relative lesser content of such elements in the onshore pre-tsunamigenic ilmenite grains reveals that the chemical leaching has not been active compared to the ilmenite concentrates from the shallow sea that have been brought by the tsunami and also to that have been deposited earlier and now seen underneath up to a depth of $\sim 5 \mathrm{~m}$.
\end{abstract}




\section{INTRODUCTION}

The tsunami struck the southern Kerala coast at 11.30 am and the central Kerala coast by 12. 30 pm on 26 December 2004. The tsunami run ups resulted in 172 casualties and an estimated loss of property worth Rs.1358.6 crores. Eyewitnesses conveyed that three waves have struck the low lying coastal plains sequentially and resulted in considerable damages. The impacts of tsunami mineralo -granulometic evaluation of beach placers of Kerala state have already been studied [1]. The effect of tsunami on sediments as well as floral and faunal assemblages have been reported elsewhere [2-9]. Occurrences of higher concentrations of economical heavy minerals (placers) in the coastal zone have created interest for exploration and exploitation of these marine mineral resources in many parts of the world [10-16]. Study of mono-mineralic analysis such as ilmenite, sillimanite, zircon, garnet and rutile has been considered more informative than the analysis of bulk sediments for understanding the geologic-geochemical characteristics [17]. Of these, the geochemistry of ilmenite holds an important role in the assessment of its quality since ilmenite has high demand in several industries. Further, ilmenite is identified as an object for provenance search by varietals method [18-19]. The major ilmenite reserves in India are at Chavara, Manavalakurichy and Chatrapur. India stands first in terms of ilmenite reserves which are estimated to be 348Mt out of which $150 \mathrm{Mt}$ were processable. This paper reports the effect of tsunami in the ilmenite population using XRD, SEM-EDX and ICPAES.

\section{GEOLOGIC SETTING OF THE STUDY AREA}

The modern black sand placer of the Thottappally - Kayamkulam (Fig.1) barrier island, with an average width of about $250 \mathrm{~m}$ between the lagoon to the east and Laccadive sea to the west, extends for about $20 \mathrm{~km}$ and at least $2-5 \mathrm{~km}$ width towards inland. The foreshore slopes at a low angle seaward $\left(4-10^{\circ}\right)$ and the direction of longshore current remains in general, northerly in this segment [20]. Sporadic occurrence of a clay horizon having organic matter with peat is observed from 2.5 to $4 \mathrm{~m}$ depth, where heavy mineral concentration becomes less significant. The hinterland area consists of crystalline rocks of Archeaen age, sedimentary rocks of Tertiary period and laterite capping on crystalline and sedimentary rocks belonging to Recent to subRecent. Climate in Kerala experiences a humid tropical with alternate wet and dry seasons. The temperatures vary from 22 to $35^{\circ} \mathrm{C}$ and the highest temperatures fall during March to May and the lowest in December and January. Humidity in Kerala varies from 79-84\% in the morning's hours to $73-77 \%$ in the evenings. As far as annual rainfall concerned, Kerala receives 200-300 $\mathrm{cm}$ during the southwest monsoon i.e June - September and the northeast monsoon (OctoberDecember) yields about $50 \mathrm{~cm}$ rainfall. The longshore sediment transport largely depends on the wave approach and also on the near shore topography. In general, along the west coast, the breaker angles were generally $5-10^{\circ}$ during pre- and post-monsoon seasons and during monsoon they changed to $160-170^{\circ}$ thus indicating a reversal in the direction of the longshore current 
[21]. The breaker height in the Chavara coast ranges from $0.3-0.5 \mathrm{~m}$ during pre-monsoon season; during monsoon and post-monsoon, it varies from 1.0-2.0m [20]. Groins at mouth bar of Kayamkulam bar also play a significant role in concentration of black sand deposits in the study area.

\section{MATERIALS AND METHODS}

Along the Thottappally - Kayamkulam barrier island representative surficial sediment (pretsunami and post tsunami event) samples were collected from the berm using a scooper up to a depth $30 \mathrm{~cm}$ and four core samples following cable tool method up to $5 \mathrm{~m}$ depth in 2004 and 2005 respectively. The samples were initially washed and dried and representative samples were treated with $1: 10 \mathrm{HCl}, 30 \%$ by volume $\mathrm{H}_{2} \mathrm{O}_{2}$ and $\mathrm{SnCl}_{2}$ to remove carbonates, organic matter and ferruginous coatings respectively. The samples were then sieved at a +GF+ DIN 4188 sieve shaker for 15 minutes at half Phi interval [22]. Magnetite was separated from the heavy mineral fractions by a hand magnet. Magnetic (ilmenite) and non-magnetic fractions were separated using Frantz Isodynamic separator. Forward slope of $15^{\circ}$ and a slide tilt of $12^{\circ}$ at $0.5 \mathrm{Amp}, 0.4$ Amp and 0.15 Amp were to separate ilmenite mineral.

X-ray diffraction using Philips (X'pert pro) powder diffractometer, $\left(2^{\circ} / \mathrm{min}\right.$ from $20^{\circ}$ to $\left.60^{\circ}\right)$ were carried out on ilmenite to understand mineral alteration. The pure ilmenite samples were mounted on carbon adhesive tape and imaged using Jeol-JSM 5600 LV field emission scanning electron microscope and analysed with a EDAX light element energy dispersive X-ray spectrometer using a $20 \mathrm{kV}$ electron accelerating voltage. Images of the various samples were also collected at $5 \mathrm{kV}$ in order to obtain high-resolution surface characteristics of the mineral grains. The EDAX composition of selected grains was determined at $10 \mathrm{kV}$. Powdered ilmenite was brought into solution by fusion with $\mathrm{KHSO}_{4}$ and dissolution in hot dilute $\mathrm{H}_{2} \mathrm{SO}_{4}$. Titanium was determined by reducing titanium (IV) to titanium (III) using aluminum metal and titrating it against standard ferric ammonium sulphate [23]. The total iron was estimated by stannous chloride reduction- $\mathrm{K}_{2} \mathrm{Cr}_{2} \mathrm{O}_{7}$ titration method. The content of $\mathrm{FeO}$ in the ilmenite was analysed by treating the powdered ilmenite with $\mathrm{HF}-\mathrm{H}_{2} \mathrm{SO}_{4}$ mixture and titrating it with standard $\mathrm{K}_{2} \mathrm{Cr}_{2} \mathrm{O}_{7}$ [24]. The trace elemental composition studies are carried out using ICP-AES (IRIS INTREPID II XSP MODEL, Thermo Electron Corporation make). 


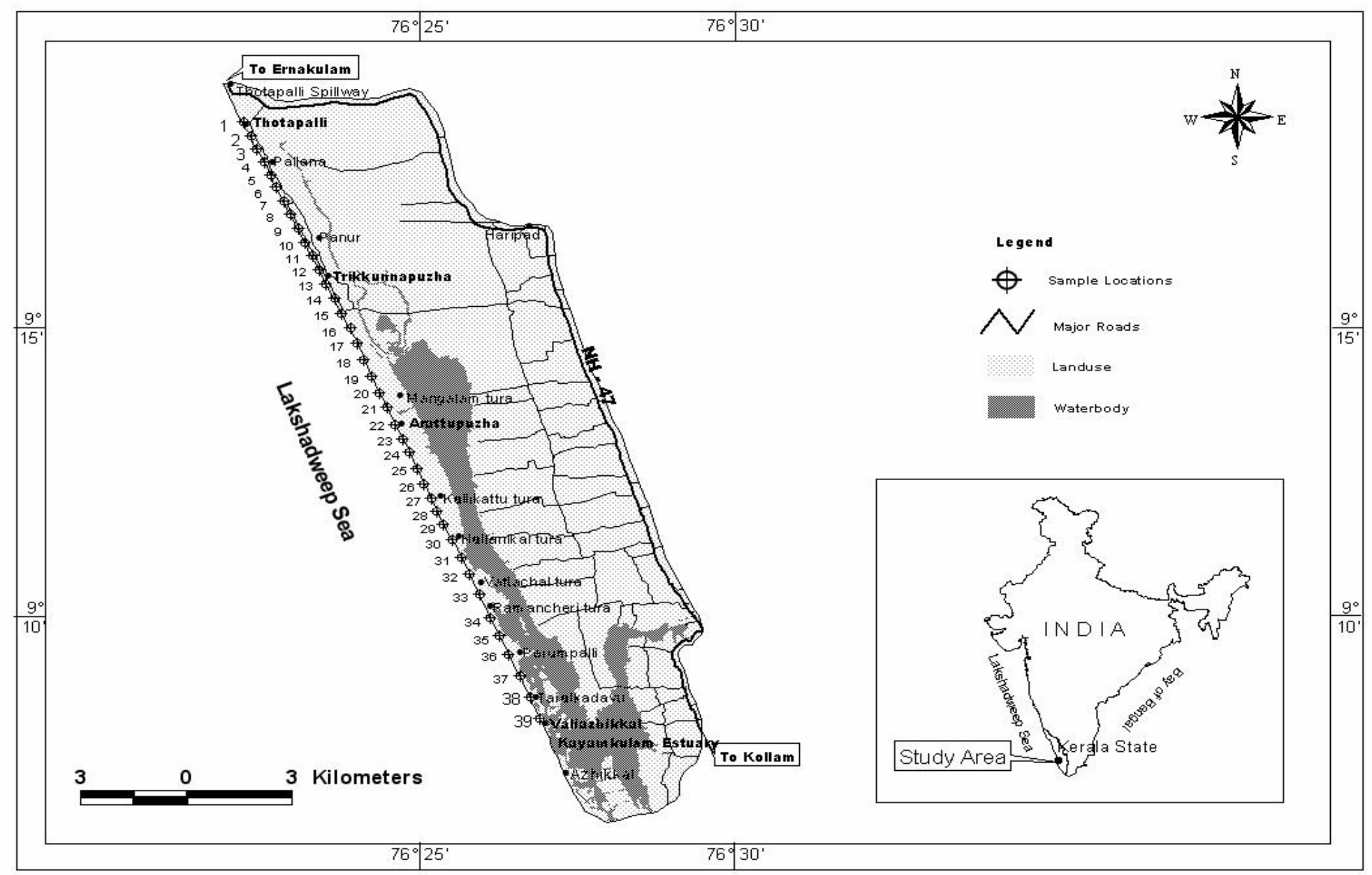

Figure 1 Location and sampling point in the study area 


\section{RESULTS AND DISCUSSION}

Altogether nineteen samples have been analysed for different major, minor and trace elements contents (Table 1, 2), of which eight samples (3, 10, 13, 22, 28, 34 and 39) were collected before the tsunami and three samples (3T, 13T and 39T) after the tsunami. Four samples each were collected from the sub-surface layers, below and above water table respectively (Table 2). Above water table and below water table samples belong to those samples collected from sub-surface (Core).

\subsection{XRD Analysis}

X-ray diffraction pattern of the ilmenite concentrate of Thottappally - Kayamkulam shows the presence of ilmenite (50\%) and rutile (50\%) peaks in the pre-tsunami samples (Fig 2a), while in the core and post-tsunamic it shows ilmenite (20 and 41\%), rutile (25 and 16\%), pseudorutile and pseudobrookite (55 and 50\%) peaks (Fig. 2b-d). This means that the grains are apparently more altered in the core and post-tsunamic samples, which could be due to the sporadic burial under reducing conditions in water-logged soils would provide the ideal environment for such alteration to occur and mixing of shelf sediments with the onshore sands. The shelf of the Kerala coast may host older sediments and possibly more altered or the shelf sediments could have been subjected to intense weathering due to sub aqueous conditions.

\subsection{SEM Analysis}

Micromorphological studies of ilmenite pre-tsunami (Fig. 3 a-e), post-tsunamic and core (Figs. 4a-f and 5a-j) from the study area by SEM depict the development of a number of different micro features on the ilmenite grain which support the XRD evidences. From these features one could understand the physical and chemical energy gradient, surface and sub-surface dissolution process, and post depositional diagenitic modifications [25-26]. The surface textures of quartz grains used in order to achieve an understanding of the post-depositional or diagenitic history of the sediments [27]. Pre-tsunamic ilmenite grains exhibits subrounded shape along with impact 'V' marks and deep pits are seen resulting from mechanical collision and later from solution activity. Mechanical feature like V-shaped pits suggest that grains are formed by grain to grain collision in an aquatic medium [28-29]. Crescentic structures and pits are produced by solution activity. Due to long residence time this type of features might have developed on the grains. Sets of grooves oriented at different angles developed over the grains clearly indicate the solution activity process (Fig. 3a-e). More precipitation corroded features are visible in the posttsunamic and core ilmenite grains (Fig. 4a-f and Fig. 5f, h and j) which were presumably developed due to the chemical activity and solution activities prevailed over the grain surface which replaced the ilmenite by pesudorutile and rutile. It is clear that core and post-tsunamic ilmenite grains have undergone extensive weathering and alteration than surface ilmenite which 
supports XRD and wet chemical analysis results. Similar features have been observed in nonopaques along the east coast of India [30]. Undulatory wavy surfaces formed due to solution effect and removals of blocks were also observed on tsunami and core ilmenite grains (Fig.4 e, $\mathrm{f}$ and 5a-e, g and j). The post-tsunamic sediments might have been transported from the shelf region of Kerala Coast where sporadic burial under reducing conditions in water-logged soils would provide the ideal environment for such alteration to occur or partly formed due to the reworking of deeper onshore sediments that were lying below the water table.

Table 1 Major Elemental Distribution in Beach Ilmenite of Thottappally-Kayamkulam Deposit

\begin{tabular}{|c|c|c|c|c|c|c|c|}
\hline & S.No. & $\mathrm{TiO}_{2}$ & $\mathrm{FeO}$ & $\mathrm{Fe}_{2} \mathrm{O}_{3}$ & T.Iron & $\mathrm{Ti} / \mathrm{Ti}+\mathrm{Fe}$ & Alt.Stage \\
\hline \multirow{12}{*}{$\begin{array}{l}\text { Surface (pre- } \\
\text { tsunami) }\end{array}$} & 3 & 60.83 & 8.96 & 24.81 & 24.32 & 0.60 & PR \\
\hline & 4 & 64.20 & 8.94 & 26.75 & 25.66 & 0.58 & HI \\
\hline & 6 & 64.66 & 9.11 & 26.52 & 25.63 & 0.58 & HI \\
\hline & 10 & 61.83 & 8.88 & 25.92 & 25.03 & 0.58 & HI \\
\hline & 13 & 60.48 & 8.47 & 26.16 & 24.88 & 0.59 & HI \\
\hline & 18 & 63.58 & 9.20 & 26.66 & 25.80 & 0.58 & HI \\
\hline & 22 & 61.66 & 9.05 & 26.66 & 25.68 & 0.59 & HI \\
\hline & 24 & 61.45 & 9.22 & 26.56 & 25.75 & 0.57 & HI \\
\hline & 28 & 61.10 & 9.12 & 24.79 & 24.43 & 0.58 & HI \\
\hline & 30 & 63.69 & 8.74 & 25.75 & 24.80 & 0.59 & HI \\
\hline & 34 & 64.10 & 8.79 & 28.27 & 26.60 & 0.57 & HI \\
\hline & 39 & 62.13 & 9.03 & 25.15 & 24.61 & 0.60 & PR \\
\hline \multirow{8}{*}{ CORE } & $1 \mathrm{c} 2$ & 63.07 & 6.71 & 25.57 & 23.10 & 0.62 & PR \\
\hline & $2 c 2$ & 63.56 & 7.55 & 25.46 & 23.68 & 0.62 & PR \\
\hline & $3 c 2$ & 62.94 & 6.72 & 27.39 & 24.38 & 0.61 & PR \\
\hline & $4 c 2$ & 64.40 & 7.87 & 25.69 & 24.09 & 0.62 & PR \\
\hline & $1 c 4$ & 63.67 & 7.85 & 25.33 & 23.82 & 0.61 & PR \\
\hline & $2 c 4$ & 62.06 & 6.92 & 27.31 & 24.48 & 0.62 & PR \\
\hline & $3 c 5$ & 63.79 & 6.74 & 25.92 & 23.37 & 0.62 & PR \\
\hline & $4 c 6$ & 66.08 & 9.28 & 24.36 & 24.25 & 0.62 & PR \\
\hline \multirow{3}{*}{$\begin{array}{l}\text { Surface (post- } \\
\text { tsunami) }\end{array}$} & 3T & 62.86 & 7.81 & 25.28 & 23.47 & 0.61 & PR \\
\hline & $13 T$ & 62.45 & 7.32 & 25.82 & 23.75 & 0.61 & PR \\
\hline & 39T & 62.01 & 6.75 & 27.84 & 24.72 & 0.60 & PR \\
\hline
\end{tabular}




\begin{tabular}{|c|c|c|c|c|c|c|c|c|c|c|c|c|c|c|c|c|c|c|c|}
\hline \multirow[b]{3}{*}{ Elements } & \multirow{2}{*}{\multicolumn{8}{|c|}{ Surface (pre-tsunami) }} & \multicolumn{8}{|c|}{ Core } & \multirow{2}{*}{\multicolumn{3}{|c|}{$\begin{array}{l}\text { Surface (post- } \\
\text { tsunami ) }\end{array}$}} \\
\hline & & & & & & & & & \multicolumn{4}{|c|}{$\begin{array}{c}\text { Sub-Surface Above } \\
\text { Water Table }\end{array}$} & \multicolumn{4}{|c|}{$\begin{array}{c}\text { Sub-Surface Below } \\
\text { Water Table }\end{array}$} & & & \\
\hline & 3 & 10 & 13 & 18 & 22 & 28 & 34 & 39 & $1 \mathrm{c} 2$ & $\begin{array}{l}2 \mathrm{c} 2 \\
\%\end{array}$ & $3 c 2$ & $4 c 2$ & $1 c 4$ & $2 \mathrm{c} 4$ & $3 c 5$ & $4 \mathrm{c} 6$ & 3T & 13T & 39т \\
\hline Al & 0.49 & 0.619 & 0.5 & 0.545 & 0.47 & 0.896 & 0.236 & 0.59 & 0.859 & 0.509 & 0.446 & 0.332 & 1.304 & 1.097 & 0.446 & 0.955 & 0.78 & 0.5 & 0.63 \\
\hline Mg & 0.49 & 0.239 & 0.46 & 0.654 & 0.49 & 0.372 & 0.145 & 0.47 & 0.635 & 0.238 & 0.221 & 0.163 & 1.368 & 0.439 & 0.213 & 0.44 & 0.49 & 0.52 & 0.55 \\
\hline $\mathrm{Mn}$ & 0.37 & 0.141 & 0.35 & 0.402 & 0.36 & 0.304 & 0.092 & 0.35 & 0.283 & 0.117 & 0.121 & 0.158 & 0.137 & 0.344 & 0.214 & 0.345 & 0.35 & 0.39 & 0.4 \\
\hline $\mathrm{Na}$ & 0.014 & 0.15 & 0.042 & 0.158 & 0.081 & 0.501 & 0.193 & 0.276 & 0.254 & $\begin{array}{l}0.138 \\
\text { ppm }\end{array}$ & 0.484 & 0.239 & 0.314 & 0.693 & 0.078 & 0.483 & 0.298 & 0.127 & 0.083 \\
\hline $\mathrm{Ca}$ & 249.4 & 384.1 & 206 & 1686 & 513.7 & 299.3 & 845.4 & 104.4 & 2362 & 1132 & 234.1 & 259.2 & 3499 & 1024 & 236.3 & 1019 & 207.8 & 591.6 & 1084 \\
\hline Cd & 0.7 & 2.7 & 1 & 3.2 & 1.2 & 0.1 & 0 & 0.7 & 4 & 0 & 3.1 & 0 & 0 & 26.5 & 6.1 & 15.1 & 0.9 & 0.9 & 0.9 \\
\hline Co & 60.4 & 298 & 61.9 & 672.2 & 62.1 & 618.3 & 116 & 62.2 & 602.8 & 197 & 274.3 & 260.4 & 185.7 & 671.2 & 431.5 & 697.2 & 63.1 & 70.5 & 69.2 \\
\hline $\mathrm{Cr}$ & 812.8 & 264.7 & 851.2 & 601.3 & 750.1 & 729.2 & 118.7 & 833.9 & 631.1 & 173.3 & 246.7 & 293.7 & 243.8 & 668.9 & 538.9 & 888.3 & 1067 & 863.1 & 922.9 \\
\hline $\mathrm{Cu}$ & 309 & 0 & 309.3 & 0 & 274.7 & 0 & 0 & 307.5 & 0 & 0 & 0 & 0 & 0 & 0 & 0 & & 296.8 & 332.8 & 323.6 \\
\hline $\mathrm{K}$ & 0 & 218 & 19.7 & 594.2 & 24.7 & 86.1 & 245.4 & 4.9 & 144.7 & 139.9 & 76.2 & 142.6 & 556.6 & 303.8 & 79.6 & 192.7 & 13 & 31.5 & 22 \\
\hline Li & 2.8 & 0 & 3.6 & 0 & 2.1 & 0 & 0 & 2.2 & 0 & 0 & 0 & 0 & 0 & 0 & 0.3 & 0 & 3.5 & 2.9 & 2.8 \\
\hline $\mathrm{Ni}$ & 18.8 & 0 & 21.2 & 0 & 17.4 & 11.7 & 0 & 17.8 & 0 & 0 & 0 & 0 & 0 & 0 & 3 & 9.1 & 16.4 & 18.2 & 18.4 \\
\hline $\mathrm{Sr}$ & 23.1 & 0 & 23.2 & 0 & 26.6 & 0 & 0 & 20.2 & 0 & 22.3 & 19 & 25.1 & 60.9 & 0 & 49.8 & 87.1 & 24.3 & 27.6 & 39.7 \\
\hline $\mathrm{Zn}$ & 192.2 & 40.2 & 189.1 & 0 & 190.3 & 115.3 & 0 & 176.3 & 132.3 & 0 & 0 & 0 & 0 & 166.5 & 0 & 192.6 & 187.7 & 282 & 202.1 \\
\hline $\mathbf{P}$ & 518.7 & 147.8 & 457.9 & 99 & 341 & 27.1 & 17.6 & 421.1 & 451.5 & 121.9 & 99.7 & 121.7 & 304 & 247.2 & 147.6 & 211.5 & 529.3 & 340.5 & 407.5 \\
\hline $\mathrm{Pb}$ & 0 & 1072 & 0 & 2240 & 0 & 74 & 218.4 & 0 & 137 & 123.2 & 282.5 & 181.5 & 206.8 & 7149 & 320 & 5010 & 0 & 0 & 0 \\
\hline
\end{tabular}




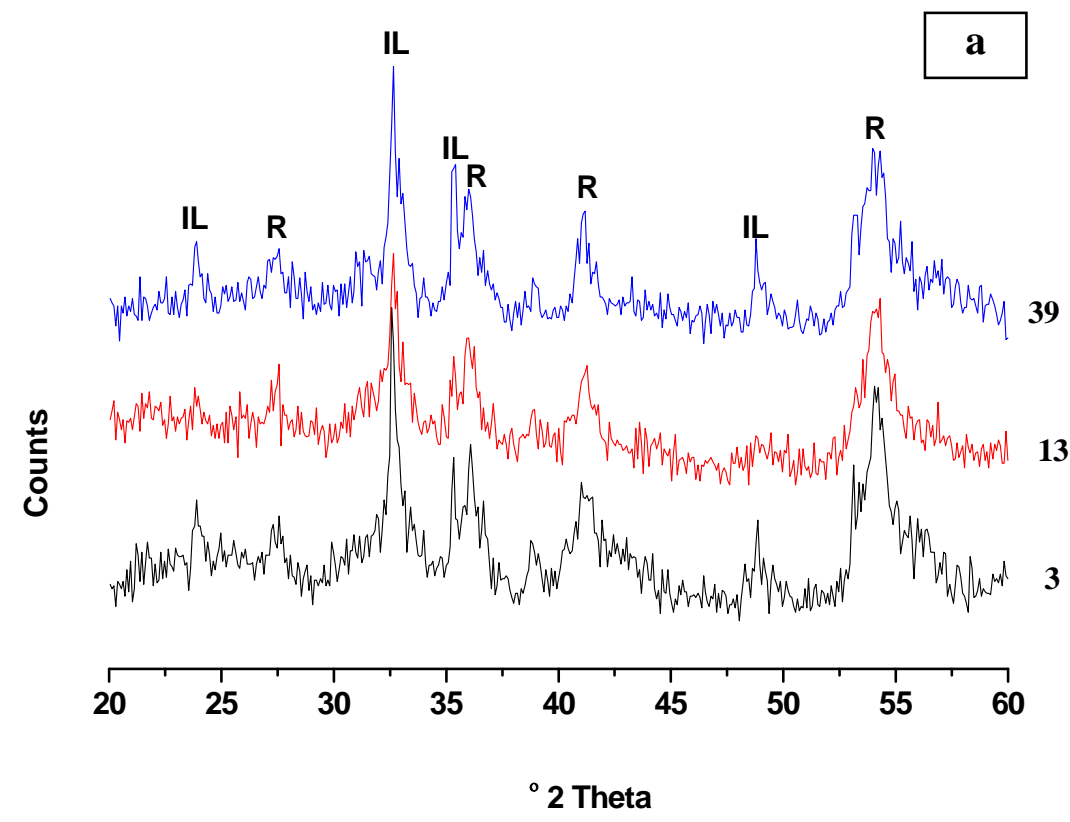

Fig. 2a X- Ray diffractrograms of representative ilmenite shows the presence of ilmenite and rutile in the pre-tsunami surface ilmenite.

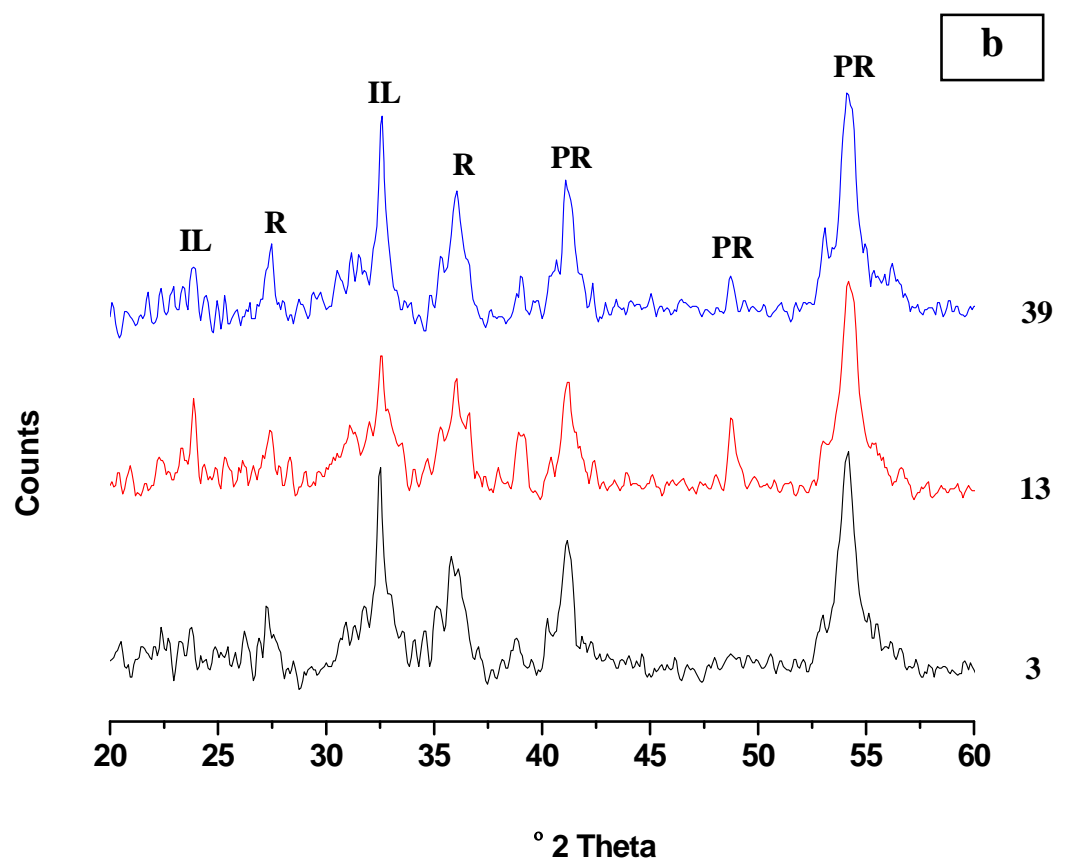

Fig. 2b X-Ray diffractrograms of representative ilmenite Above Water Table (Core) shows the presence of pesudorutile, ilmenite and rutile 


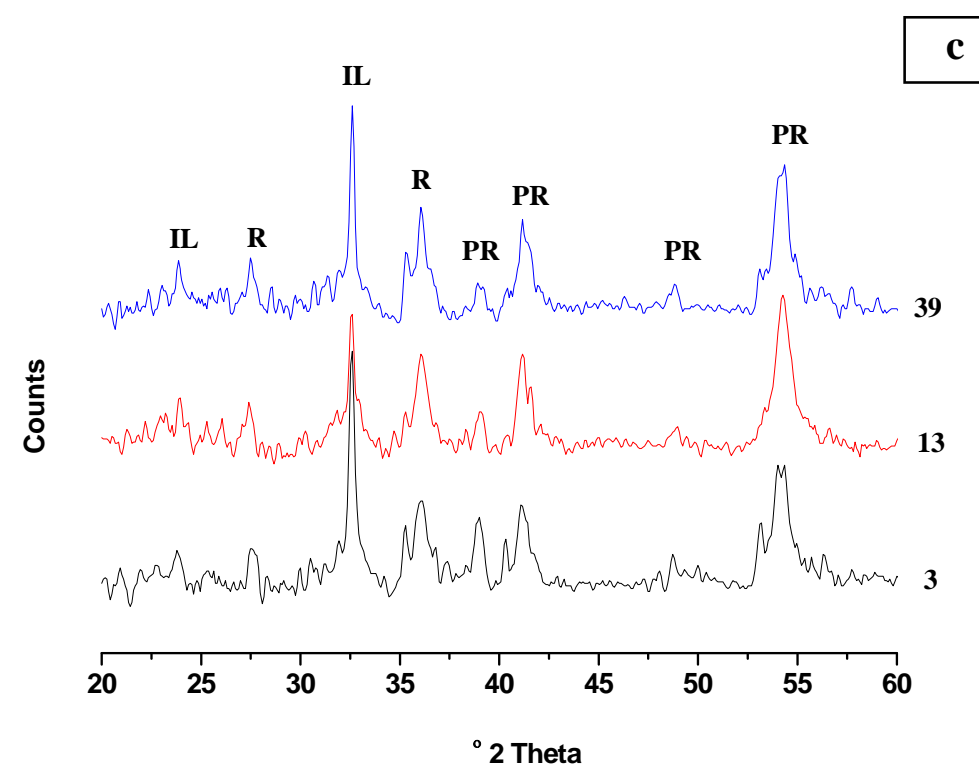

Fig. 2c X-Ray diffractrograms of representative ilmenite Below Water Table (Core) shows the presence of pesudorutile, ilmenite and rutile

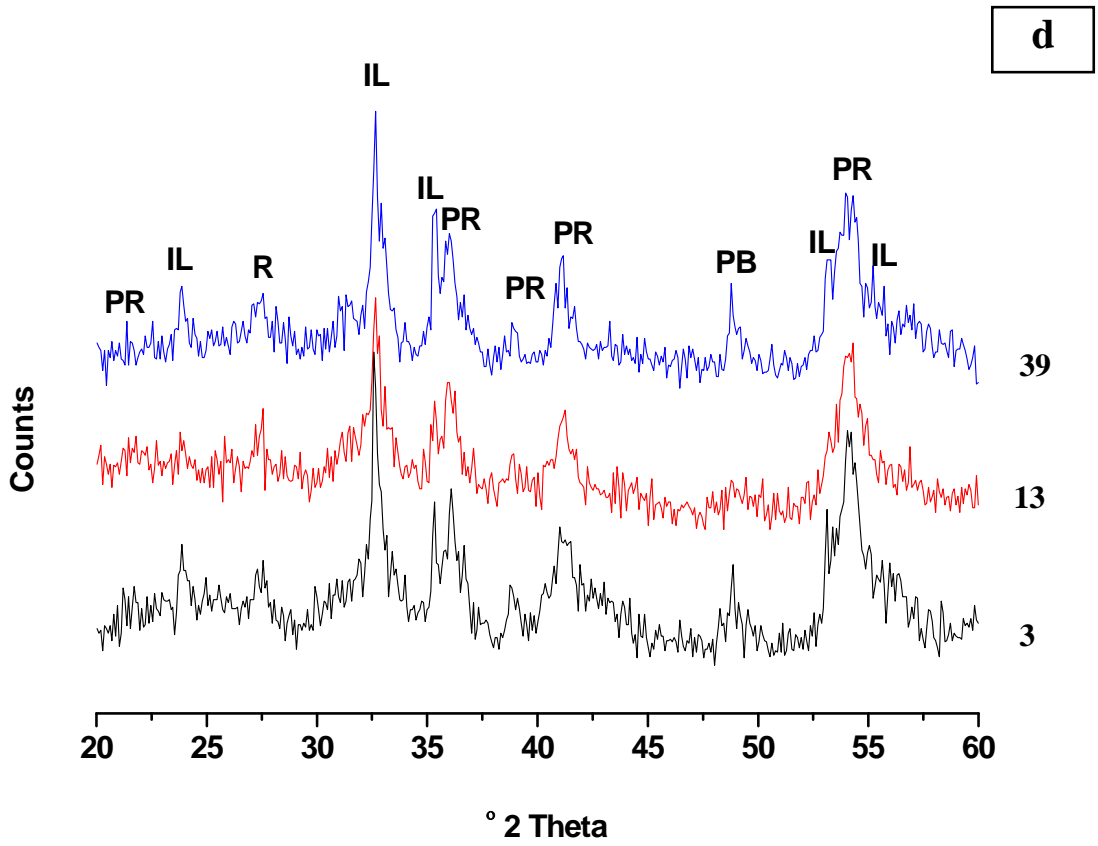

Fig. 2 d X-Ray diffractrograms of representative ilmenite shows the presence of ilmenite, rutile, pesudorutile, pesudobrookite in the post-tsunami samples. (Legend: $I L=$ Ilmenite, $R=$ Rutile, $P R=$ Pseudorutile and $P B=$ Pseudobrookite) 

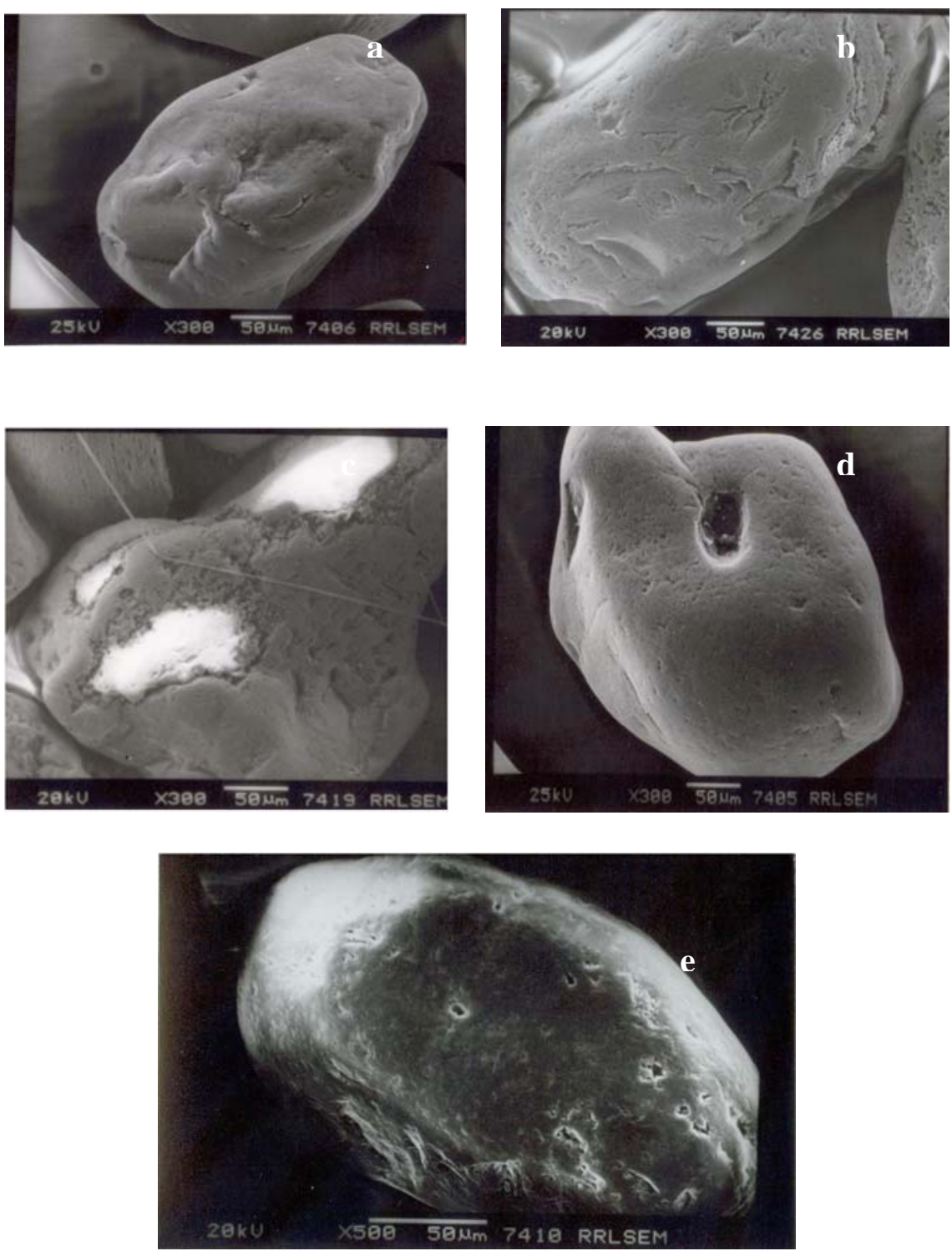

Fig. 3 a-e Scanning electron microscopic view of ilmenite grains separated from pre-tsunami samples. 

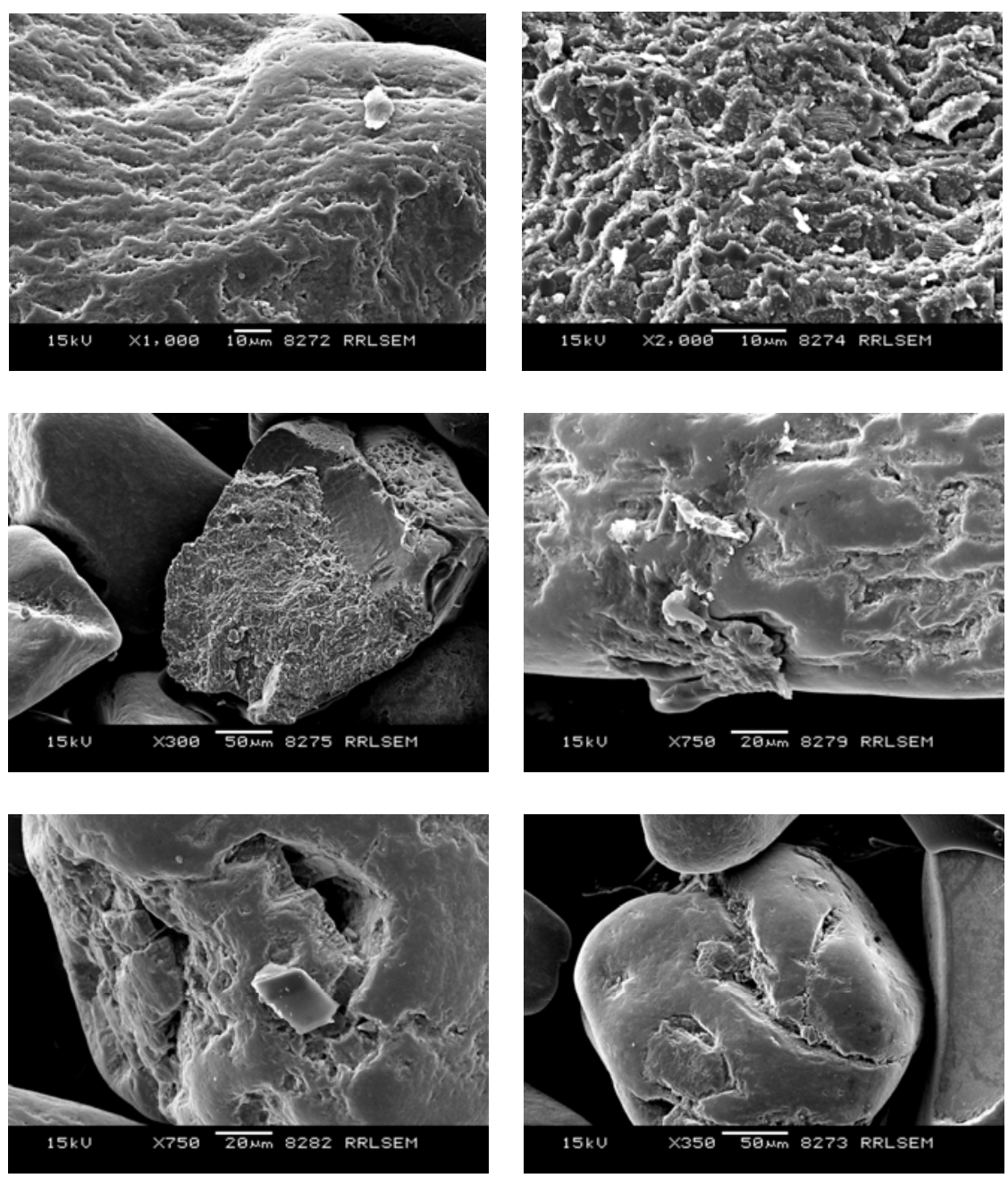

Fig. 4 a-f Scanning electron microscopic view of ilmenite grains separated from posttsunami samples. Note the intensity changes in the post-tsunami samples.

\subsection{Chemical Analyses}

\subsubsection{Wet chemical analysis}

Major elemental compositions of the ilmenite samples of pre-tsunami, post-tsunamic and drill core sediments analysed by wet chemical method [24] are summarized in Table I. Alteration stages of ilmenite under weathering also studied [31]. Abundance of $\mathrm{TiO}_{2}$ in the pre-tsunami ilmenite sediments are relatively high, range from 60.48 to $64.1 \%$ (av. $62.48 \%$ ) and in core ilmenites concentrations average $63.70 \%$, ranging from 62.94 to $66.08 \%$. On average the tsunami ilmenite contains 62.44\% $\mathrm{TiO}_{2}$, ranging from 62.01-62.86 \%. FeO and $\mathrm{Fe}_{2} \mathrm{O}_{3}$ concentrations in the pre-tsunami ilmenites range from 8.47 to 9.22 and 24.79 to $28.27 \%$ with averages of 8.96 and $26.16 \%$, respectively. The range of $\mathrm{FeO}$ and $\mathrm{Fe}_{2} \mathrm{O}_{3}$ in the core ilmenite show 6.71 to 9.28 and 24.36 to $27.39 \%$ with averages of 7.46 and $25.88 \%$, respectively. The 
contents of $\mathrm{FeO}$ and $\mathrm{Fe}_{2} \mathrm{O}_{3}$ in post-tsunamic ilmenite range from 6.75 to 7.81 and 25.28 to $27.84 \%$ (av. 7.29 and 26.31\%). It was observed that the enrichment of $\mathrm{TiO}_{2}$ in the core and posttsunamic ilmenite might have undergone deep weathering and alteration more than the pretsunami ilmenites. Core ilmenites and post-tsunamic ilmenite show pseudorutile alteration phase (Table 1), whereas most of pre-tsunami ilmenites show only hydrated ilmenite phase. A higher amount of $\mathrm{TiO}_{2}$ present in ilmenites of pre-tsunami, tsunami and core is ascribable to higher presence of rutile and pseudo-rutile exsolved phases. The above observations were supported by XRD and SEM examination (Fig. 2a-d and Fig. 3a-c , 4a-f and 5a-j) Dissolution and / or oxidation of iron from ilmenite in natural water or in acidic water lead to an enrichment of titanium and other elements in the residuum, which may be the main cause for ilmenite alteration [32]. The higher amount of $\mathrm{TiO}_{2}$ may be ascribed to repeated cycles of burial and exhumation of sediments along beaches and streams and river banks during transport [33]. This would keep ilmenite under conditions well-suited to the removal of iron for considerable lengths of time. The main reason for such a high alteration below ground water levels (core ilmenites) is due to the low Eh, high $\mathrm{pH}$ and high $\mathrm{SO}_{4}$ content in the ground waters of the study area [34] and complexing with organic acids under such reducing conditions would further enhance the solubility of iron [35]. Humic acids as a collection of organic acids resulting from the decomposition of vegetation [36]. Thus both of these leaching agents would be present in near surface zones and no doubt contribute to weathering. Organic matter enrichments were found in the core sediments during procurement of sampling in the study area. Hence, the extent of alteration of ilmenite depends not only on the geological history of the deposits but also the intensity of subsurface chemical leaching the deposits underwent in a low energy, sub surface condition. 

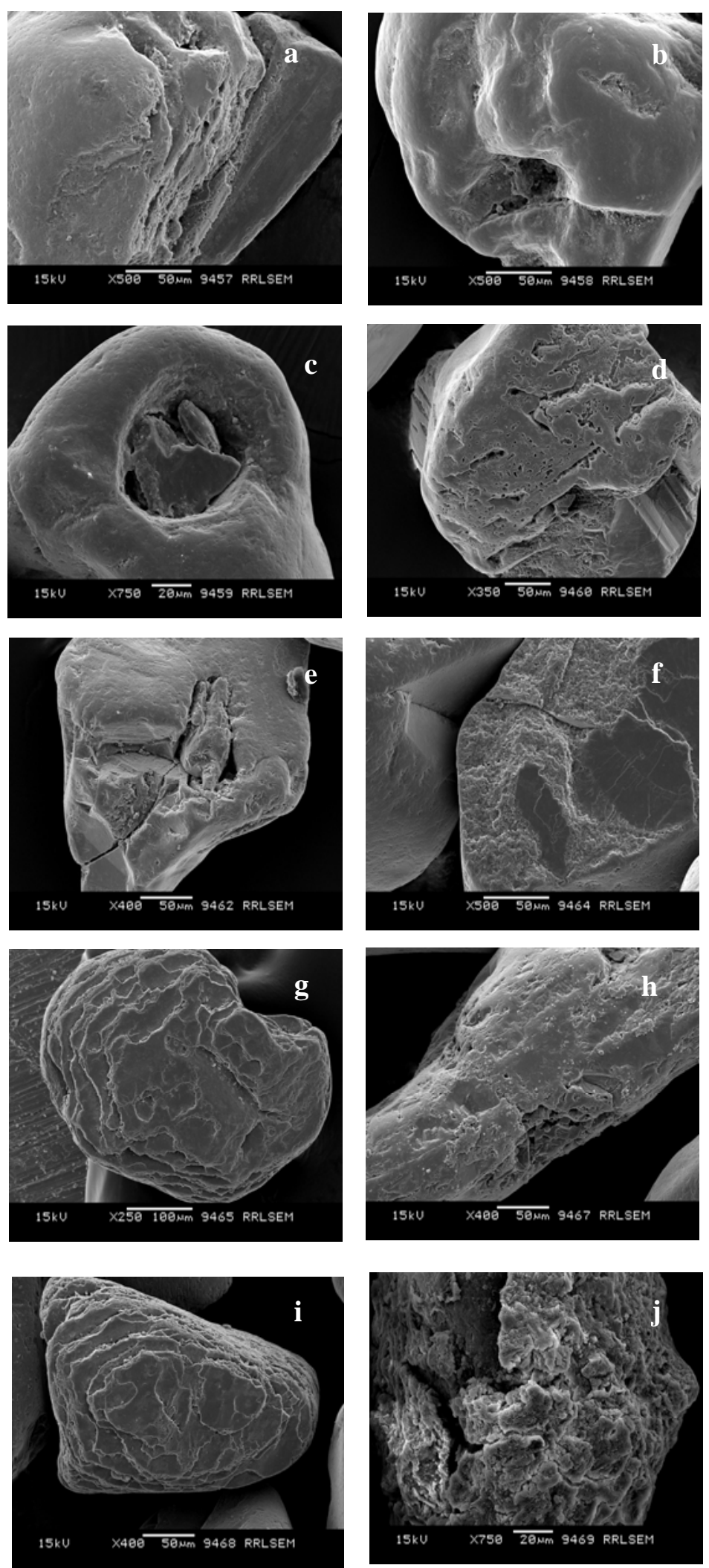

Fig . 5 a- j Scanning electron microscopic view of ilmenite (Core samples) 


\subsubsection{Minor and trace element concentration}

Major, minor and trace element concentration were analysed using ICPAES method. These elements are important in the modern mineralogical panorama, as they provide witness for the provenance of mineral suite, the alteration patterns and trend of minerals and the quality of raw mineral ores before industrial processing. Ilmenite trace element variation is dependent on its paragenesis [37-38]. The surface pre-tsunami, core (AWT and BWT) and surface post-tsunamic ilmenite samples in the present study were analysed (Table 2) for seventeen minor and trace elements, namely, Fe, Al, Mg, Mn, Na, Ca, Cd, Co, Cr, Cu, K, Li, Ni, Sr, Zn, P and Pb. These elements were selected based on their relevance in the delineation of weathering history and parentage.

Figure 6a-f shows behavioral pattern of each element determined in ilmenite collected from beach sands i.e., surface pre-tsunamic,core (AWT and BWT) and surface post-tsunamic. It was observed that elements like $\mathrm{Al}, \mathrm{Mg}, \mathrm{Na}, \mathrm{Ca}, \mathrm{Cd}, \mathrm{Co}, \mathrm{K}, \mathrm{Sr}$ and $\mathrm{Pb}$ have higher contents in ilmenite from core ilmenite. i.e., ilmenite from below water table than the ilmenite from above water table, pre- and post-tsunamic ilmenite which supports dissolution and / or oxidation of iron from ilmenite in natural water or in acidic water leading to an enrichment of titanium and other elements in the residuum. This may be the main cause for ilmenite alteration [32] and the alteration products could be due to the exogenic processes that operated on these ilmenites after their release from the parent rocks [39]. The higher contents present in core ilmenite (BWT) is ascribed to the local concentration of such elements.

The assay data in Table 2 and Fig. 6 show strong positive correlations ( $r>0.85)$ were observed between the concentrations of $\mathrm{Fe}$ and $\mathrm{Cr}, \mathrm{Ni}$ and $\mathrm{Zn}$ and between $\mathrm{Mn}$ and $\mathrm{Mg}$ and $\mathrm{Cr}$ and $\mathrm{Mn}$, and also between $\mathrm{Cu}$ and $\mathrm{Li}, \mathrm{Ni}, \mathrm{Sr}$ and $\mathrm{Zn}$ and positive concentration of element pairs Li-Ni, LiSr, Li-Zn and Li-P, Ni-Sr, Ni-Zn and Ni-P, and Cd-Pb and Sr-Zn and Sr-P in the surface ilmenite (pre-tsunami) concentrates. $\mathrm{Mg}$ and $\mathrm{Al}$ concentrations are generally high at beaches where also $\mathrm{Cr}$ and $\mathrm{Fe}$ concentrations are the highest, although there is no significant positive correlation between Al-Mg where as a strong positive correlation exists between $\mathrm{Cr}$-Fe in the pre-tsunami ilmenites. Negative or poor relationships for $\mathrm{Zn}$ and $\mathrm{K}$ suggest a differing control for these elements. 

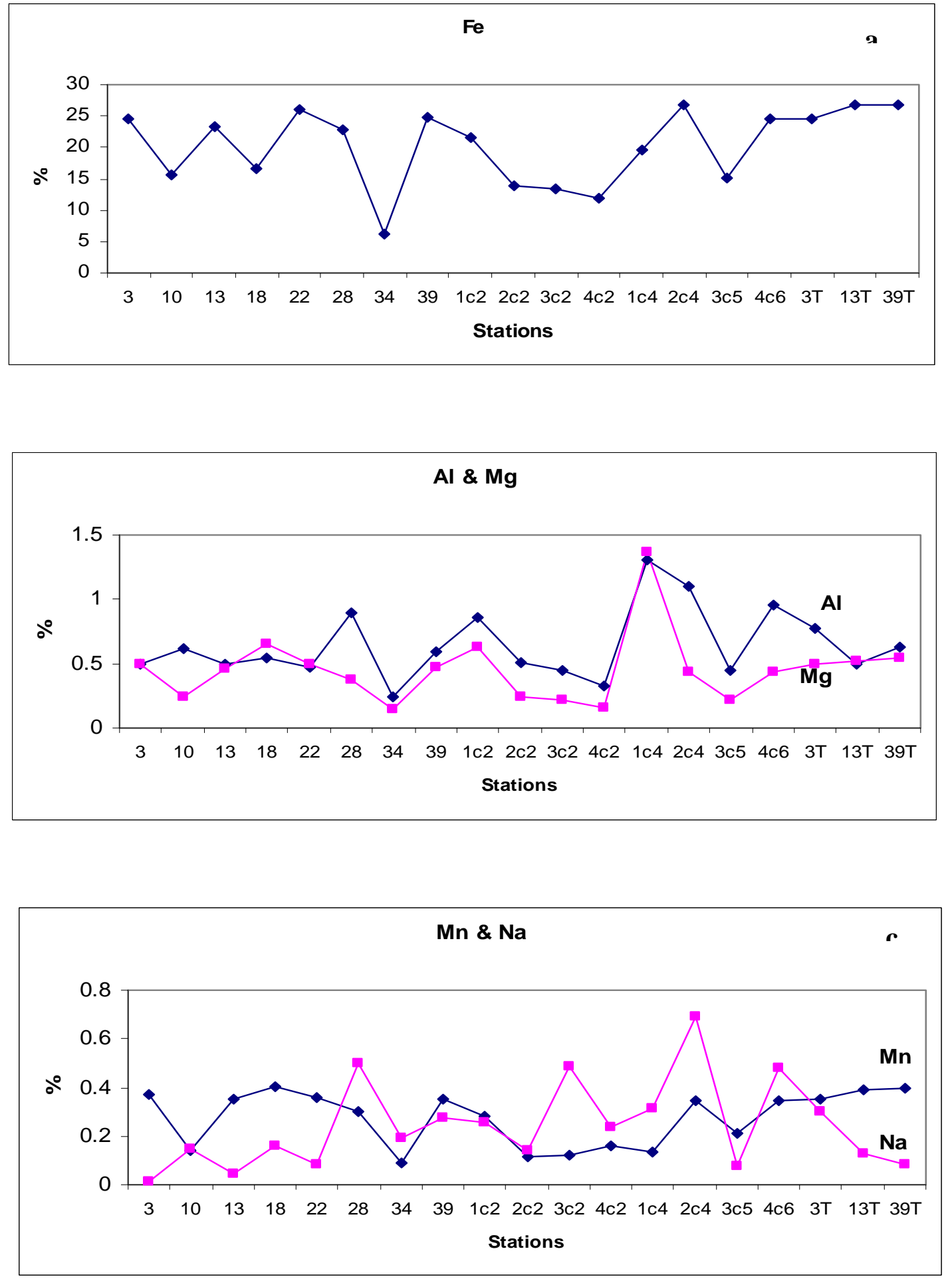

Fig. 6a-f Comparisons of minor and trace element distrinbution in beach ilmenite of Thotappally-Kayamkulam deposit. 

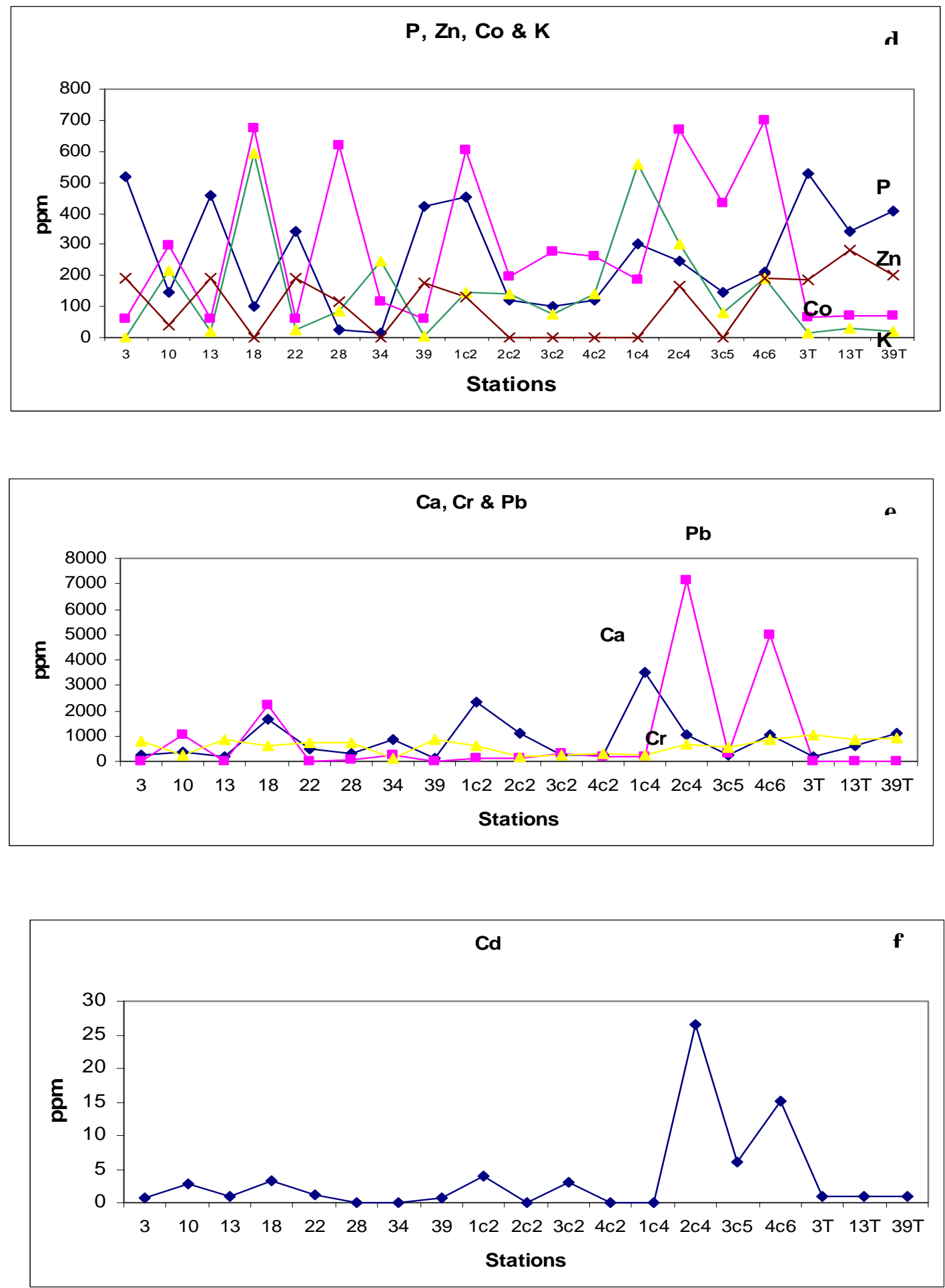

Fig. 6a-f conti... 
Non-significant correlations for $\mathrm{Al}, \mathrm{Mg}, \mathrm{Mn}, \mathrm{Na}, \mathrm{Cd}$ and Co reflect a different source or difference in substitution of other cations in the ilmenite structure during crystallization.The substitution of other cations in the ilmenite structure is controlled by several factors including the temperature of crystallization, oxygen fugacity, the amount of suitable cations available, and the size, charge, and electronegativity of those cations relative to iron and titanium during crystallization [40]. High element concentrations but with much lower value belong to drill core ilmenites also evident from the correlation coefficient. Very strong and positive correlations exist among the concentrations of elements pairs Al-Fe, Mn-Fe, Cd-Fe, Zn-Fe, Mg-Al, K-Al, Cd-Mn, Co-Mn, Cr-Mn, Zn-Mn, Co-Cd, Pb-Cd, Zn-Cr and Pb-Zn. Negative concentration of element pairs $\mathrm{Al}-\mathrm{K}, \mathrm{Mn}-\mathrm{Na}, \mathrm{Mn}-\mathrm{Li}, \mathrm{Cr}-\mathrm{K}$ and $\mathrm{Li}-\mathrm{Sr}$ and positive concentration of element pairs $\mathrm{Mg}-\mathrm{Ca}, \mathrm{Na}-\mathrm{Li}$ and $\mathrm{Cr}-\mathrm{Pb}$ were found in tsunami ilmenites. Over all high concentration of $\mathrm{TiO}_{2}$, Fe, Mg, Al, Cr, Ni, Zn and Mn recorded in beach sediments from the surface, core as well as post-tsunamic ilmenites are in good agreement with composition of Khondalites and Charnokitic rocks which are widely distributed on coastal hinter land [41] (Soman, 1985)

\section{CONCLUSION}

Titanium enrichment, predominately through removal of iron, is widespread among ilmenite populations of post-tsunamic and core samples than pre-tsunami ones. The pre-tsunamigenic (surficial) ilmenite grains consist only of rutile as an altered product with a small $\mathrm{FeO}-\mathrm{Fe}_{2} \mathrm{O}_{3}$ ratio. However, the presence of considerable altered products such as rutile and pseudorutile in the post-tsunamigenic and subsurface ilmenite indicates that the ilmenite alteration is in an advanced state. Chemical alteration of ilmenite predominates over mechanical abrasion as exemplified by the SEM investigation in the post-tsunamic as well sub-as surface (core) sediments than pre-tsunami (surface) ilmenites. Regarding trace element data, it was found that $\mathrm{Al}, \mathrm{Mg}, \mathrm{Na}, \mathrm{Ca}, \mathrm{Cd}, \mathrm{Co}, \mathrm{K}, \mathrm{Sr}$ and $\mathrm{Pb}$ have higher contents in both core and post-tsunamigenic ilmenite than the pre-tsunamigenic. The relative lesser content of such elements in the onshore pre-tsunamigenic ilmenite grains reveals that the chemical leaching has been less active compared to the ilmenite concentrates from the shallow sea that have been brought by the tsunami and also to that have been deposited earlier and now seen underneath up to a depth of $\sim 5 \mathrm{~m}$.

\section{ACKNOWLEDGEMENT}

We acknowledge CSIR New Delhi for funding and Director NIIST, Thiruvanthapuram, for extending Laboratory Facilities. First author's due thanks to the organizer of ICAM 2008, which was held at Brisbane, Australia for given opportunity to present this paper in the international congress on Applied Mineralogy. Special thanks due to Dr. D.S. Suresh Babu, Scientist, Center for Earth Sciences Studies, Kerala, India for fine tuning the manuscript. 


\section{REFERENCES}

[1] Babu. N, Suresh Babu D S and Mohan Das, P N, (2007). Impact of tsunami on texture and mineralogy of a major placer deposit in southwest coast of India. Environ Geol, 52: 71-80

[2] Leatherman, S P, Williams T A, and Fisher S, 1977. Overwash sedimentation associated with a large-scale northeaster. Marine Geology, 24:109-121.

[3] Nanayama, F, Shigeno, K, Satake, K, Shimokawa, K. Koitabashi, S, Miyasaka, S, and Ishii M, 2000. Sedimentary differences between the 1993 Hokkaido-nan sei-oki tsunami and the 1959 Miyakojima typhoon at Taisei, southwestern Hokkaido, northern Japan. Sedimentary Geology, 135: 255-264.

[4] Szczucinski W, Niedzielski, P, Rachlewicz, G, Sobczynski , T, Ziola, A, Kowalski A, Lornec S, and Siepak, J, 2005. Contamination of tsunami sediments in a coastal zone inundated by the 26 December 2004 tsunami in Thailand. Environ. Geol, 49(2): 321-331

[5] Kumaraguru, A K, Jayakumar, K, Jerald Wilson, J and Ramakritinan C M, 2005. Impact of the tsunami of 26 December 2004 on the coral reef environment of Gulf of Mannar and Palk Bay in the southeast coast of India , Current Science, 89 (10): 1729 - 1741.

[6] Ramachandran, S, Anitha, S, Balamurugan, V, Dharanirajan, K, Ezhil Vendhan, K, Marie Irene Preeti Divien, Senthil Vel, A, Sujjahad Hussain, I and Udayaraj, A. 2005. Ecological impact of tsunami on Nicobar Islands (Camorta, katchal, Nancowry and Trinkat), Current Science, 89(1): 145 - 200.

[7] Gusiakov, V K, 2005. Tsunami generation potential of different tsunamigenic regions in the Pacific. Marine Geology, 215: 3-9.

[8] Perez-Torrado, F J, Paris, R, Cabrera, C M, Schneider Jean-Luc, Wassmer, P, Carracedo Juan-Carlos, Rodriguez-Santana A and Santana F, 2006. Tsunami deposits related to flank collapse in oceanic volcanoes: The Agaete Valley evidence, Gran Canaria, Canary Islands. Marine Geology, 227: 135-149.

[9] Goff J, Dudley W C, deMaintenon M J, Cain, G, and Coney J P, 2006. The largest tsunami in $20^{\text {th }}$ century Hawaii. Marine Geology ,226: 65-79.

[10] Perissoratis, C, Angelopoulos, I and Mitropoulos, D, 1987. Exploring the offshore area of N.E. Greece for placer deposits: geologic framework and preliminary results. In (eds: P G Telesis, M R Dobron, J R Moore and U V Stackelberg), Marine Minerals: Advances in Research and Resource Assessment, Proceeding ARW, Aberystwyth (Wales) 588, D. Reidel Company 588, 57-70.

[11] Berquist, C R, Fishler Jr, C T, Calliari, L J, Dydak, S M, Ozalpaslan, H, and Skrabal, S A, (1990). Heavy-mineral concentrations in sediments of the inner continental shelf. in (ed: C R Berquist Jr), Heavy-Mineral Studies-Virginia Inner Continental Shelf, Virginia Div. Mineral. Resource. Publication. 103: 31-94.

[12] Li, M Z, and Komar, P D, 1992. Longshore grain sorting and beach placer formation 
adjacent to the Columbia River, Jour Sed Petrol 62(3): 429-441.

[13] Cook, P J, Fannin, N G T, and Hull, J H, (1992). The physical exploitation of shallow seas. in (eds: K.J. Hsü and J. Thied), Use and Misuse of the Seafloor, John Wiley \& Sons, pp, 157-180.

[14] Schwartz, M O, Rajah, S S, Askury, A K, Putthapiban, P and Djaswadi, S, 1995. The Southeast Asian tin belt, Earth Science Review, 38: 95-293

[15] Roy, P S, 1999. Heavy mineral beach sand placers in Southeastern Australia: their nature and genesis: Economic Geology, 94: 567-588.

[16] Gent, M R, Alvarez, M N, Iglesias, J M G, and Alvarez, J T, 2005. Offshore occurrences of heavy-mineral placers, Northwest Galicia, Spain, Marine. Georesource Geotechnology, 23: 39-59.

[17] Morton, A C, 1985. Heavy minerals in provenance studies. in: (ed: G G Zuffa) Provenance of Arenites. Reidel, Dordrecht, pp, 249-277.

[18] Darby, D A. and Tsang, Y W, (1987). Variation in ilmenite composition within and among drainage basins implications for provenance. J Sed Petrol, 57 (5):831-837.

[19] Grigsby, J D, 1992. Chemical finger printing in detrital ilmenite; A viable alternative in provenance research? Jour Sed Petrol, 62 (2): 331-337.

[20] Prakash, T N, and Varghese, A.P, 1987. Seasonal beach changes along Quilon District Coast, Kerala. Journal of Geological Society of India, 29: 390-398.

[21] Narayanaswamy, G, Udaya Varma, P and Abraham Pylee, 1979. Wave climate of Trivandrum (Kerala). Mahasagar, Bull. National Institute of Oceanography, 12: 127-133.

[22] Folk, R L. and Ward, W C, 1957. Brazos River Bar: A study in the significance of grain size parameters. Jour Sed Pet, 27(1): 3-26.

[23] Jelks Barksdale, 1966. Titanium its Occurrence, Chemistry and Technology, The Ronald Press Company, New York.

[24] Agarwal, B C and Jain, S ,P, (1976). A textbook of Metallurgical Analysis, Khanna publishers. Delhi.

[25] Setlow L W and Karpovich, S, 1972. Glacial microtextures on quartz and heavy mineral sand grains from the littoral environment, $J$ Sed Petrol., 42: 864-875.

[26] Morton A.C, 1984. Stability of detrital heavy minerals in Tertiary sandstones from the North Sea Basin, Clay Mineralogy 94: 287-308.

[27] Krinsley, D H, and Doornkamp, J C, 1973. Atlas of Quartz Sand Surface Textures. Cambridge University Press, Cambridge, p 37.

[28] Higgs R, 1979. Quartz grain surface features of Mesozoic-Cenozoic sands from the Labrador and western Greenland continental margins, Jour Sed Petrol, 49: 599 - 610.

[29] Mallik, T K, 1986. Micromorpholgy of some placer minerals from Kerala beach, India, Mar Geol, 71(3)-(4): 371-381. 
[30] Cherian, A, Chandrasekar, N and Rajamanickam, V, (2004). Light minerals of beach sediments from Southern Tamil Nadu, south east coast of India. Oceanologia, 46 (2): 233252

[31] Frost, M T, Grey, I E, Harrowfield, I R and Mason K, 1983. The dependence of alumina and silica contents on the extent of the alteration of weathered ilmenite from Western Australia. Mineral Magazine, 47: 201-208.

[32] Dimanche, F and Bartholome, P, (1976). The alteration of ilmenite in sediments. Minerals Science Engineering, 8: 187-201.

[33] Lener, E F, 1997, Mineral Chemistry of Heavy Minerals in the Old Hickory Deposit, Sussex and Dinwiddie Counties, Virginia, Blacksburg, Virginia, Unpublished M.Sc., Thesis.

[34] Bass Becking, L G M, Kaplan, I T and Moore, D, (1960). Limits of the natural environment in terms of $\mathrm{pH}$ and oxidation-reduction potentials. J Geol, 68: 243-284.

[35] Drever, J I and Vance, G F, 1994. Role of soil organic acids in mineral weathering processes. In (eds: E D Pittman and M D Lwean) Organic Acids in Geological Processes. Springer-Verlag, Berlin, 138-161.

[36] Lynd, L E, 1960. Study of the mechanism and rate of ilmenite weathering. AIME Trans. 217: 311-318.

[37] Hutton, C O, 1950. Study of heavy detrital minerals. Bull Geol Soc Amer, 61: 635-716.

[38] Buddington, A F and Lindsley, D H, (1964). Iron-titanium oxide minerals and synthetic equivalents. J. Petrol, 5: 310-357.

[39] Rao, D S, Vijayakumar, T V, Prabhakar, S, Bhaskar Raju, G and Ghosh, T K, 2005. Alteration characteristics of ilmenites from south India. Jour. of Minerals and Materials Characterization and Engineering, 4(1): 47-59.

[40] Lister, G F, 1966. The composition and origin of selected iron-titanium deposits. Econ. Geol. 61: 275-310.

[41] Soman, K, 1985. Origin and geologic significance of the Chavara deposit, Kerala, Current Science, 54: 280-81. 